\title{
STUDENT SCIENCE AND TRAINING ENGINEERS
}

\author{
Viktor Shebashev*, Yuri Andrianov, Lyudmila Nizova, Anna Nikitina \\ Volga State University of Technology, Russian Federation
}

The authors contemplate the forms of student science and their role in training engineers based on the documents of the International Labor Organization for Human Resources Management and Vocational Training: a case of technical universities in the Volga Federal District of the Russian Federation. The articles gives the dynamics of innovation-driven growth of Volga State University of Technology (Volgatech), students' publication activity, students' participation in the "UMNIK" programme and the number of incentives that the students were awarded at the Olympiads and competitions (with a breakdown by engineering professions). Based on monitoring, the authors define the tendency of Volgatech graduates' employment (with a breakdown by integrated groups of majors of engineering graduates).

Key words: Student science, Student, Engineer, Production, HEI, Innovative methods of training, Employment of engineering graduates, Labor market

\section{INTRODUCTION}

Personnel training and retraining is a special issue in the work of the International Labor Organization. The organization broadly views the problem of human resource development, including such issues as governance development, career guidance and occupational rehabilitation. A number of conventions and recommendations substantiate the organization's viewpoint. The recommendation No.57 "On Vocational Training" (1937) was one of the first normative acts, which gave definition of such training, described the basics for the content of programmes, andaddressed the issues of pre-vocational training and vocational training prior to and during employment.

The issues is best discussed in the Recommendation No.117 "On vocational training" (1962), the Convention No.142, supplemented by the Recommendation No.150 "On Human Resources Development" (1975), the Article 1 states: "Each Member shall adopt and develop comprehensive and co-ordinated policies and programmes of vocational guidance and vocational training, closely linked with employment, in particular through public employment services".

The conventions and recommendations comprise agreed goals, principles, obligations of employers and workers in the field of policies and initiatives of vocational training. The basic principles of the training policy stipulate that:

- all workers shall be given equal access to vocational training and employment should be ensured without discrimination on any grounds;

- national policies and programmes are designed to encourage citizens to develop their ability to work, primarily in their own interests, as well as taking into account the needs of countries;

- training systems should meet the needs of young people and adults for lifelong learning;
- national policies and training programmes should be designed and implemented by the government in close cooperation with entrepreneurs and workers organizations.

These principles are fundamental of the Constitution of the Russian Federation (Article 37), according to which every citizen has the right to be in command of his/her abilities to work. This right presumes special importance when there is a problem of training and further employing graduates by profession. Modern economic system deploys two types of employment technologies for engineering graduates: traditional and non-traditional (innovative). Traditional technologies are knownand stipulated by the law of the Russian Federation "On employment of the population in the Russian Federation" [1]. The main forms of employment promotion are: assistance to citizens in finding suitable work; information support on the situation in the labor market; arranging and holding job fairs; career guidance, job placement, and vocational training; psychological support, vocational training and professional development of unemployed citizens.

However, the above mentioned types of policy in the times of financial and economic crisis are losing their relevance, so, the methodology is poorly adapted to the modern economic system; traditional technologies do not encourage economic activity of engineering graduate, but rather provoke frustration in the chosen profession [2].

\section{THEORY AND EXPERIMENT}

Nowadays the Russian government has launched the process to support the leading regional universities to facilitate their cooperation with local industries. More than 70 percent of universities have become active partners of the representatives of local industries, which stimulated the growth of regional economy.

The collaboration between academic institutions and various branches of industry includes: small innovative 
enterprises, specialized departments, technology incubators, start-ups, as well as collaboration in the field of research and development.

Improved training of engineers is a priority took in the context of innovative economy [3].

Monitoring demonstrated that over the past six years, the highest proportion of graduates employed was in Russia and in the Volga Federal District (VFD) in 2010, while in the Republic of Mari El (RME) the highest proportion was in 2011. The lowest indicator for all Russian territories was in 2015 (76.8\% - the Russian Federation, 74.4\% the VFD, and $79.9 \%$ - the RME.) Generally, the share of graduate employment in the Russian Federation is $75 \%$, including the region of residence - 64\%.) [5].

The main reasons for the decline in employment are as follows: there is no balance between the labor market and the market of educational services - the universities educate graduates the local economy does not call for. The latter results in the second problem - many specialists settle down in subject of the Russian Federation respectively.

Author's monitoring proved that the highest rate of employment in the region is typical of the Far Eastern Federal District $(72 \%)$, the North-Western and the Volga Federal Districts (67\%), and the lowest is - the Central (57\%) and Siberian (58\%) Federal Districts (Table 1).

Statistical surveydemonstrated that the highest level of employment in the Volga District is characteristic of Kazan National Research Technical University n.a. A. N. Tupolev (85\%), Nizhny Novgorod State Technical University n.a. R.E. Alekseev (90\%), M.T. Kalashnikov Izhevsk State Technical University (90\%), Ulyanovsk State Technical University (90\%). Meanwhile, the anal- ysis showed that there are RussianHEls with the minimum employment indicators, including the University of Russian Innovative Education (30\%), Ulyanovsk Civil Aviation Institute n.a. the Chief Marshal of Aviation B.P. Bugaev (24\%), and Tomsk State University of Control Systems and Radioelectronics (33\%) [5].

The dynamics of the graduates' employment mad it evident that, the most popular majors of training at Kazan National Research Technical University n.a. A.N. Tupolev are the following: Materials Engineering (94.7\%), Techno sphere Safety and Environmental Engineering (94.2\%), and the least popular are Methods and Technology of Ground Transport Vehicles (83.5\%), Mechanic Engineering (85\%). The most popular majors of training at Nizhny Novgorod State Technical University n.a. R.E. Alekseev are Aeronautic and Rocket-and-Space Equipment (97\%), Mathematics and Mechanics (94\%), while the least popular majors are Methods and Technology of Ground Transport Vehicles (85\%), Materials Engineering (84\%). The most popular majors of training at Kalashnikov Izhevsk State Technical University are Computer Science and Computer Engineering (95\%), while the least popular majors are Aeronautic and Rocket-and-Space Equipment (75\%). The most popular majors at Ulyanovsk State Technical University are Photonics, Tool Engineering, Optical and Biotechnical Systems and Technologies (90\%), where the least popular majors are Architectural Studies (56\%).

Graduates' training in the interests of specific enterprises based on cooperation and partnership should be prioritized [6]. The Russian labor market can becharacterized by an excessive external mobility, which is substantiated by high labor turn-over rates (hiring and firing rates) and low rates of jobtenure.

Table 1: Graduates' employment by federal districts

\begin{tabular}{|c|c|c|c|c|c|c|}
\hline \multirow{2}{*}{ Name of the federal district } & \multicolumn{5}{|c|}{ Share of employment by years } \\
\cline { 2 - 7 } & \multicolumn{2}{|c|}{2014} & \multicolumn{2}{c|}{2015} & \multicolumn{2}{c|}{2016} \\
\cline { 2 - 7 } & $\begin{array}{c}\text { Share of the } \\
\text { employed }\end{array}$ & $\begin{array}{c}\text { Employed in } \\
\text { the region }\end{array}$ & $\begin{array}{c}\text { Share of the } \\
\text { employed }\end{array}$ & $\begin{array}{c}\text { Employed in } \\
\text { the region }\end{array}$ & $\begin{array}{c}\text { Share of the } \\
\text { employed }\end{array}$ & $\begin{array}{c}\text { Employed in } \\
\text { the region }\end{array}$ \\
\hline Central Federal District & $80 \%$ & $62 \%$ & $80 \%$ & $58 \%$ & $80 \%$ & $57 \%$ \\
\hline $\begin{array}{c}\text { North-Western Federal } \\
\text { District }\end{array}$ & $80 \%$ & $74 \%$ & $80 \%$ & $68 \%$ & $80 \%$ & $67 \%$ \\
\hline $\begin{array}{c}\text { Southern Federal District } \\
\text { North-Caucasian Federal } \\
\text { District }\end{array}$ & $75 \%$ & $71 \%$ & $75 \%$ & $67 \%$ & $75 \%$ & $65 \%$ \\
\hline Volga Federal Districts & $80 \%$ & $71 \%$ & $80 \%$ & $68 \%$ & $80 \%$ & $67 \%$ \\
\hline Ural Federal District & $80 \%$ & $69 \%$ & $85 \%$ & $66 \%$ & $80 \%$ & $65 \%$ \\
\hline Siberian Federal District & $75 \%$ & $58 \%$ & $80 \%$ & $60 \%$ & $80 \%$ & $58 \%$ \\
\hline Far Eastern Federal District & $75 \%$ & $77 \%$ & $80 \%$ & $74 \%$ & $75 \%$ & $72 \%$ \\
\hline \hline
\end{tabular}


Our hypothesis is that external mobility dominates (in comparison with the internal one) and is largely compensatory, being a reaction to the existing limitations for internal promotion [7].

This has negative impact not only on the labor market, but also on the development of the economy, especially on the industrial sector. In the case of the Republic of Tatarstan the level of graduates' employment is $80 \%, 75 \%$ of which are graduates employed in the region, which contributed to a high rating on the socio-economic status among the subjects of the Russian Federation (5th in the rating). In the Perm region, the level of employment is $88 \%, 83 \%$ of graduates find work in the region; this results in the high 15th place in the Russian rating. We are observing a contrary situation in the Republic of Mordovia, where out of $70 \%, 56 \%$ of graduates were employed in the region and, thus, the republic ranked 63rd among Russian districts. The Republic of Mari El ranks 69th in terms of socio-economic development, with $75 \%$ of graduates employed $(64 \%$ of which are employed in the region [6].

Volga State Technological University sees enhancing the quality of engineering training as priority in the context of an innovative economy. First, this should be implemented and supported by innovative university infrastructure. Volgatech has Shared Knowledge Centre, eleven Research and Technology Centers based on unique laboratories, techno park, business-incubator, student design-engineering department, twenty-five small innovative enterprises, botanical garden-institute, and experimental forestry-enterprise. These structural units employ more than 100 students.Scientific and Educational and Scientific and Technological Centers are in the heart of the innovative university infrastructure.

Volgatech is a leader in the field of sustainable nature management based on nano-, bio-, energy-saving and infocommunication technologies.

Secondly, the university encourages students to use their innovative competencies. For that purpose teaching staff uses active forms of training, such as: business and role games, designing business plans, presentations, brainstorming, master classes, brain-rings, round tables (discussions, debates), case-study analysis, etc.

The engineering departments, as a rule, use topics related to the issues of specialist training for various manufacturing industries. There are business games "Job searching technologies and ways of employment", "Labor market and market of educational services", "Engineer is entrepreneur", etc. The Volgatech business incubator is in charge of training seminars and programmes such as: "How to Do Business" "Export, Import, Engineering, Finance, Logistics, Marketing", "Fundamentals of Entrepreneurship", "Fundamentals of Small Innovative Enterprises", "Technology Transfer and Commercialization".

The university takes part in the contest supported by the Ministry of Education and Science of the Russian Federation in the prioritized project "Modern Digital Education- al Environment", which aims at establishing a regional online learning center.

Thirdly, the university has committed to joining social partnership with real sector of the economy. University scientific and technological centers play a major role in increasing the volume of research and development work. The most important of which are: Center of Radar Systems and Complexes; Center of Sustainable Forest Management and Remote Sensing; Center for Automated Mechanical Engineering; Laboratory "New Technology"; Test laboratory of Furniture and Wood Products; Laboratory of Construction and Technical Expertise; Shared Knowledge Center "Ecology, Biotechnologies and Processes for Obtaining Environmentally Friendly Energy Carriers"; Center for the Development of Innovative Technologies in Construction; Student Design-Engineering Department; Center for Consulting in Management and Marketing; Center for Engineering and Industrial Design "Bioenergy"; Center for Expertise and Property Management.

Fourth, the university supports publication and project activities. The dynamics of the publication activity is given in Table 2, which shows that the students with engineering majors account for more than $70 \%$ of publications at the university.Students of the Institute of Civil Engineering and Architecture, as well as future specialists in the field of management and business are most active in publishing their research results [8].

The "UMNIK" programme has become very popular among students (Figure 1). Volgatech is among the top ten universities in Russia in terms of the number of projects financially supported by the Innovation Development Fund in the framework of the youth scientific and innovative competition "UMNIC" (in 2016 there were 237 of them).

Students' participation in grant activities is improving their competitiveness. The students of the Radio Engineering Faculty (over the last three years more than 30 grants), as well as the students of the Institute of Forestry and Nature Management (27 grants) are the most active in this activity. We are witnessing a steady increase in the number of medals, diplomas and certificates awarded to students at international, Russian and regional Olympiads and competitions. Figure 2 shows that there was a slight decrease in the number of incentives in 2016 compared to 2015 , but there had been a significant increase compared to 2014. This is applicable to students of the Institute of Civil Engineering and Architecture, the Faculty of Radio Engineering, the Faculty of Information Technologies and Computer Engineering [4].

Students also participate in the International Festival of Innovations, Knowledge and Inventions "Tesla Fest" (Serbia); in the International Salon of Inventions "INOVA" (Croatia); in the International Forum of Innovation Development "Open Innovations"; and in the International Exhibition "Open Innovations Expo" and many others. 
Table 2: Dynamics of students' publications at Volga State University of Technology

\begin{tabular}{|c|c|c|c|}
\hline Engineering majors & 2014 & 2015 & 2016 \\
\hline Institute of Mechanics and Machine Building (IMMB) & 243 & 35 & 92 \\
\hline Institute of Forestry and Nature Management (IFNM) & 50 & 64 & 154 \\
\hline Faculty of Radio Engineering (FRE) & 88 & 82 & 132 \\
\hline Faculty of Information Technologies and Computer Engineering (FITCE) & 34 & 29 & 52 \\
\hline Institute of Civil Engineering and Architecture (ICEA) & 161 & 98 & 216 \\
\hline Faculty of Economics & 223 & 97 & 325 \\
\hline Faculty of Management and Law & 554 & 192 & 171 \\
\hline Total for engineering majors & 1353 & 597 & 1142 \\
\hline Total at the University & 1851 & 991 & 1605 \\
\hline \hline
\end{tabular}

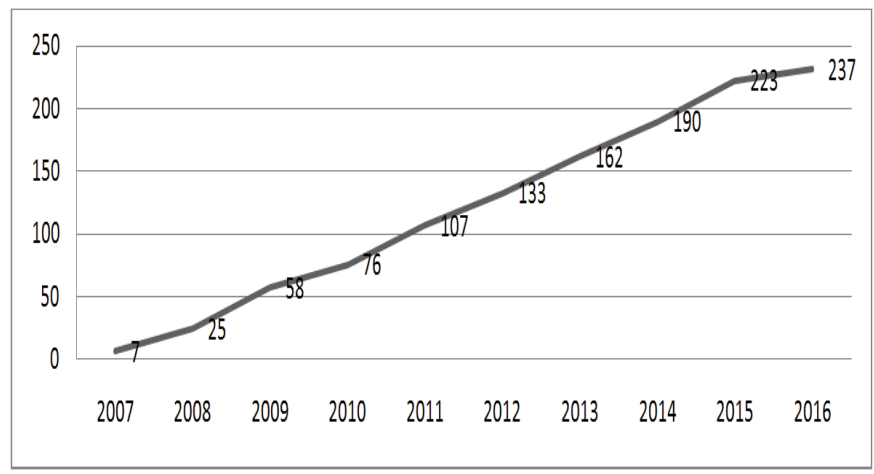

Figure 1: Results of the "UMNIK"programme at Volga State University of Technology

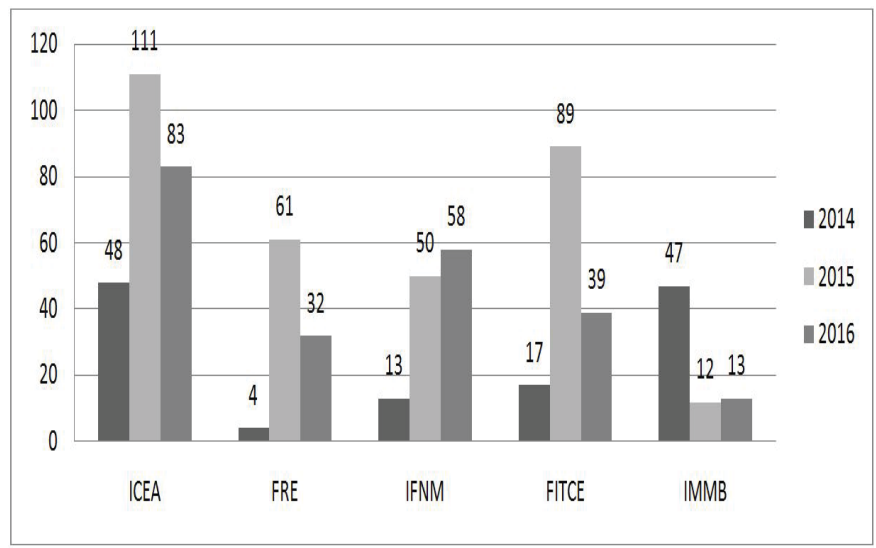

Figure 2: The number of medals, diplomas and certificates awarded to students at the Olympiads and competitions

Student science is a launching pad for scientific personnel training, thus, currently more than $200 \mathrm{PhD}$ students study at Volgatech. Consequently, for 100 full-time students of the contingent, there are 3.55 PhD students. In 2016 the university implemented $23 \mathrm{PhD}$ programmes (for those who study 1-3 years according to the Federal State Educational Standard) and $25 \mathrm{PhD}$ programmes (for those who study 4-5 years in compliance with the federal state requirements).

The study of the role of student science in the process ofengineering graduates training proved that the technology should be continuing - from school to university. Thus, "My First Step into Science" and Russian student forum "Engineering Graduates are the Future of Russia's Innovative Economy" are annually held at the university. Volgatech organizes the final rounds of the Russian Student Olympiad in Mathematics, Statistics, Robotics and Controller Programming, as well as the final rounds of the Internet Olympiads in 15 disciplines for university students in the Volga Federal District.

The accumulated experience in research is beingpractically used by Volgatech graduates who are in demand at the enterprises of the defense industry complex (hereinafter referred to as the DIC) in the Volga Federal District. Currently, 400 students are enrolled in the programme "New Personnel of the Defense Industry Complex", 85\% of which will be employed. More than two-thirds of engineers and technical support staff at enterprises of the Defense Industry Complex are graduates of Volgatech. However, the problem of graduates' employment is still seen as priority in Russia and the Republic of Mari El (Figure 3). In 2016 this indicator for Volgatech graduates fell down by 1.47 times (277 people in 2016 against 684 people in 2015).

The share of employed has decreased from $80 \%$ to $75 \%$ (table 3) according to the data of the Ministry of Education and Science of the Russian Federation.Specialists in Applied Geology, Mining, Oil and Gas and Geodesy; Machine Building; Techno sphere Safety and Environmental Engineering; Electricity and Heat Power, as well as Ag- 
riculture, Forestry and Fishery are of particular concern. According to the authors, the main reason for the decline in employment is the lack of balance between the labor market and the market of educational services - the universities educate graduates the local economy does not call for.

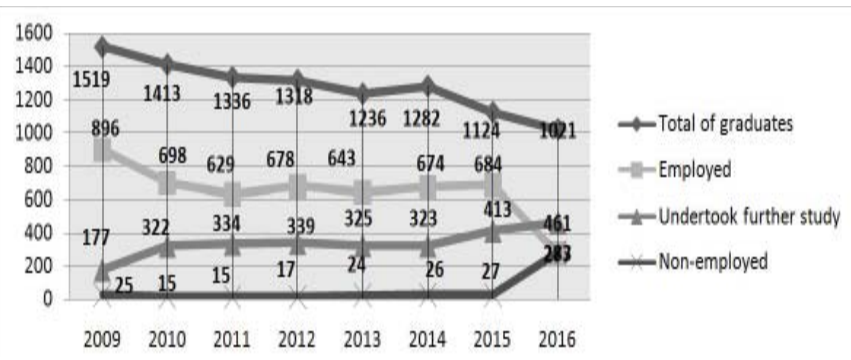

Figure 3: Dynamics of graduates' employmentat the Volga State University of Technology

To tackle the issue Volgatech has committed to joining social partnership with industrial enterprises of the republic and with real sector of the economy, thus ensuring republic's innovative-driven growth. The university is a member in the prioritized project of the Russian Federation "Universities are centers of space for innovations" which as- sures further development of the university as a leading regional engineering research and education center.

\section{CONCLUSIONS}

1. Further developing the open educational environment (infrastructure) to enhancestudents' research activity.

2. Improving the quality of education based on competence models within professional standards by the use of interactive technologies.

3. Providing a symbiosis of theory and practice based on interaction with enterprises and organizations of leading sectors of the economy, including network programmes.

4. Supporting favorable conditions for the students' participation in International, Russian and Regional Olympiads, Contests and Fora.

5. Remodeling the educational programmes (inclusion of the model of project training, updating the content of the educational programme with the inclusion of modules for training innovative entrepreneurship and commercialization of research outcomes to expand opportunities for the development of personal competencies (softskills)).

Table3: Dynamics of engineering graduates' employment atVolga State University of Technology

\begin{tabular}{|c|c|c|c|}
\hline \multicolumn{2}{|c|}{ Name of the integrated groups of majors } & \multicolumn{3}{|c|}{ Share of emloyment } \\
\hline Industrial Ecology and Biotechnology & 2014 & 2015 & 2016 \\
\hline Chemical Technologies & $\mathrm{x}$ & $85.7 \%$ & $100 \%$ \\
\hline Information Safety & $90.9 \%$ & $85.7 \%$ & $88.9 \%$ \\
\hline Electronics, Radio-Engineering and Communication System & $68 \%$ & $63 \%$ & $82.4 \%$ \\
\hline Methods and Technologies in Civil Engineering & $76.8 \%$ & $70 \%$ & $80 \%$ \\
\hline Methods and Technologies in Ground Transport Vehicles & $59.6 \%$ & $72.5 \%$ & $75 \%$ \\
\hline Materials Engineering & $94.4 \%$ & $86.7 \%$ & $75 \%$ \\
\hline Informatics and Computer Engineering & $67.1 \%$ & $75 \%$ & $72.97 \%$ \\
\hline Agriculture, Forestry and Fishery & $73.7 \%$ & $75.7 \%$ & $71 \%$ \\
\hline Heat-power Engineering & $93.2 \%$ & $79.1 \%$ & $69 \%$ \\
\hline Earth Science & $61.5 \%$ & $70.6 \%$ & $68 \%$ \\
\hline Techno Sphere Safety and Environmental Engineering & $78.7 \%$ & $69.2 \%$ & $66.7 \%$ \\
\hline Mechanic Engineering & $82.4 \%$ & $78.6 \%$ & $64.6 \%$ \\
\hline Applied Geology, Mining, Oil and Gas Geodesy & $77.8 \%$ & $100 \%$ & $63.6 \%$ \\
\hline System and Technologies & $x$ & $58.3 \%$ & $59.3 \%$ \\
\hline \hline
\end{tabular}


6. Developing e-education mechanisms, and increasing the number of applied bachelor's degree programmes, which lead to qualifications that are in demand in the region.

\section{REFERENCES}

1. Law of the Russian Federation No.1032-1, dated April 19, 1991 (amended on July 29, 2017) "On employment in the Russian Federation".http://docs. cntd.ru/document/9005389

2. Nikitina A.S.,Nizova L.M. (2015) Socialnie indicatory rinka truda vipusknikov vuza [Social indicators of the employment market of university graduates]. Ingenernie kadri-buduschee innovatsionnoi ekonomik: materiali nauchno-prakticheskoi konferentcii. [Engineering graduates are the future on the innovative-driven economy: proceedings of the research-practical conference], p.63-65.

3. Ovchinnikova N., Ovchinnikova O., Kolmykova T., Bredikhin V. (2018) New generation of regional universities in Russia. Journal of Applied Engineering Science, 16 (1), 132-141

4. Romanov E., Andrianov Y., Nizova L., Nikitina A., (2016) Engineering personnel training through the example of Volga State University of Technology, Mari El, Russia, Journal of Applied Engineering Science, 14 (1), 36-43
5. The Ministry of Education and Science of the Russian Federation [Electronic resource]. Available at: http://vo.graduate.edu.ru/registry\#/?year $=2013 \&$ slice=1\&page $=1 \quad$ (reference date: 26.11.2017);

6. Rating of socio-economic status of the subjects of the Russian Federation, results of 2016 [Electronic resource]. Available at: https://ria.ru/infografika/20170530/1495077131.html (reference date: 01.12.2017).

7. Gimpelson V.E. et al. (2016) The Pathways We Choose: Intra- and Interfirm Transitions.HSE Economic Journal. 2016,20(2), 201-242

8. Ivanov D.V., Andrianov Y.S., Nekhoroshkov P.A. (2017)Strategy of research development of the Russian Federation. Results of research activity at Volga State University of Technology in 2016. Volgatech, Yoshkar-Ola. 